\title{
Accounting as a Source of Financial Information on Insolvency in Liquidation Proceedings
}

\author{
Kinga Bauer ${ }^{1}$, Jan Hospodka²
}

Submitted: 11.07.2020. Accepted: 30.11.2020

\section{Abstract}

Purpose: The purpose of this paper was to indicate which information originating in accounting is important for ensuring the information transparency of bankruptcy proceedings.

Methodology: Based on the literature review and the analysis of international legal acts, we determined priority types of information from accounting used in bankruptcy court proceedings. These types included information on the costs of insolvency proceedings, the assumption in the financial statements that there was no going concern, and the book value of assets. A survey was then conducted on a group of specialists in the field of bankruptcy.

Findings: Respondents indicated information on the costs of bankruptcy proceedings as the most important. However, other accounting information under study also received a high assessment from insolvency specialists. The obtained assessments of individual quality features are characterized by high reliability confirmed by low standard errors.

Research implications: Accounting evolves as a response to the information needs of accounting information users. Therefore, knowing these needs may contribute to changes in the requirements regarding the scope of information from accounting that is used in bankruptcy proceedings.

Originality/value: In-depth knowledge of various aspects of the economic side of the bankruptcy phenomenon is part of the current trend in minimizing the negative effects of bankruptcy.

Keywords: accounting information, bankruptcy, insolvency by liquidation, going concern assumption, costs of bankruptcy.

JEL: M41, G33

Cracow University of Economics, Department of Accounting, 27 Rakowicka St., 31-510 Cracow, Poland, e-mail:kinga.bauer@uek.krakow.pl; https://orcid.org/0000-0002-2822-0094.

2 Jan Hospodka, PhD student, University of Economics in Prague, Department of Financial Accounting and Auditing, nam. W. Churchilla 1938/4, 13067 Praha 3 - Žižkov, e-mail: jan.hospodka@vse.cz. 


\section{Introduction}

The stakeholder theory indicates the existence of groups that influence a particular company's operations. This influence results from their interest in or claims towards the company (Donaldson and Preston, 1995; Evan and Freeman, 1999; Ogan and Ziebart, 1991; Tilt, 2007; Banasik, 2017). Despite the theory was popularized in the twentieth century, scientific research still points to the need for in-depth analyses and concepts development in this area. The shortcomings communicated in the literature concern, among other things, information flow between an enterprise and its stakeholders (e.g. Krasodomska, 2014) and the possibility of meeting the information needs of stakeholders through financial statements (e.g. Masztalerz, 2010). Moreover, due to changes in the economic environment of enterprises - along with social progress manifested through an increased level of economic knowledge in the society - the scope of information sought after is changing and expanding. Hence, there is a constant need for research in this area (Bauer et al., 2020).

The stakeholder theory applies to an enterprise in general and not to any specific conditions in which the enterprise may operate. However, the literature does reference the theory of stakeholders of enterprises in the process of restructuring or bankruptcy (cf. e.g. Morawska and Roszkowska, 2011; Bauer and Krasodomska, 2015; Linna, 2019; 2020). Despite clear indications that one of the roles of the bankruptcy process is the reduction of information asymmetry between the parties to the process (Smith and Strömberg, 2005); there is a noticeable lack of research on the flow of information between a company in bankruptcy process and its stakeholders. This article seeks to fill the research gap in this area, regarding information derived from the accounting of entities that undergo a bankruptcy proceeding. Certain information from accounting will be indicated, whose use may help to reduce information asymmetry between the parties to bankruptcy proceedings. I will examine the opinion of specialists in the field of bankruptcy in relation to selected information from accounting in reference to other information available in bankruptcy processes. The research will consist of a literature review, the analysis of selected national legal regulations, and surveys conducted on a group of specialists from Poland who have many years of experience in bankruptcy proceedings.

As mentioned above, one of the leading roles of the institution of insolvency is to reduce information asymmetry among stakeholders (Smith and Strömberg, 2005). Information needs of parties to bankruptcy proceedings relate to both the assessment of the risk of bankruptcy, the grounds for initiating court proceedings, the choice of proceeding type, and the assessment of particular stages of activities under judicial 
procedures. Research into bankruptcy risk assessment conducted in recent years combines financial and market data with other "soft information," such as legal actions, timeliness in submitting financial statements, employee loyalty, and management quality (Altman, Sabato, and Wilson, 2008; Boratynska, 2016; Boratyńska and Grzegorzewska, 2018). Similarly, Kurek (2017) notices that market value does not reflect all information. However, despite the increasing role of qualitative information in bankruptcy risk assessment, the role of financial information is still emphasized, including information derived from financial statements of indebted enterprises (Wędzki, 2015; Zorn, Norman, Butler, and Bhussar, 2017; Wójcik-Jurkiewicz and Karczewska, 2019). The significance of the information obtained from accounting for the purpose of bankruptcy proceedings is emphasized by the provisions of bankruptcy law and court proceedings. Various sources of information are used in bankruptcy proceedings; in many countries, the sources include companies' financial statements (Smith and Strömberg, 2005). There were also cases in which court files contained a set of financial statement elements larger than required by law (Bauer, 2018b). Other information available in accounting documents of indebted enterprises is also used for legal proceedings (Bauer, 2009). However, as Kurek and Górowski (2019) report, there are cases when companies violate financial reporting informational obligations and do not deliver required filings.

Bankruptcy law in a country pertains to companies with varying degrees of financial difficulty. In some countries (e.g. the USA, the Czech Republic, Slovakia) bankruptcy law applies to both bankruptcy and restructuring processes. However, there are countries such as Poland or Canada, in which separate legal acts were created for bankruptcy procedures leading to the liquidation of a debtor's assets and for judicial restructuring processes. This article will focus on entities in which insolvency by liquidation proceedings is being conducted.

We intentionally selected for testing such entities, in which the threat to the continuation of business activities has been confirmed. Despite its focus on meeting the information needs of stakeholders of entities continuing their business operations, accounting can also support stakeholders in the event of a threat or going concern assumption.

The purpose of this article is to indicate which information that originates in accounting is important for ensuring the information transparency of bankruptcy proceedings. Research indicates that information originating in accounting has priority over liquidation bankruptcy processes. Therefore, we will first conduct the literature review in order to meet the goal of this paper. Next, the analysis will cover international legal regulations of the types of information resulting from the literature review, which will serve as elements of the information base for court proceedings. Empirical research 
will follow in the last stage of the study to determine the position of specialists in the field of bankruptcy in Poland on the types of information originating in accounting that are indicated in previous research as having priority over the reduction of information asymmetry and their availability in court files as regulated by law. We will indicate certain information from accounting whose use may help reduce information asymmetry between parties to bankruptcy proceedings. The opinion of specialists in the field of bankruptcy in relation to selected information from accounting will be examined in reference to other information available in the bankruptcy process. The selection of Poland for research is purposeful. The regulations of Poland's Bankruptcy Law require the use of information derived from accounting during court proceedings (Bauer, 2018a), which in turn provides the possibility of extensive analyses. Moreover, research conducted in recent years in Poland confirms the positive assessment of bankruptcy practitioners regarding the informational role of financial statements (Bauer, 2018a; Bauer, 2018b).

Therefore, the purpose of this study is to obtain an answer to the following questions:

- Do bankruptcy specialists agree that one of the roles of bankruptcy institutions is to ensure information transparency of bankruptcy processes?

- Do bankruptcy professionals consider accounting information significant? Three types of information prioritized in the literature and legal acts were selected for the analysis, i.e. information on the costs of bankruptcy proceedings, information on the going concern assumption, and information on the book value of assets.

- Is correlation between the following important? The opinion of bankruptcy specialists on ensuring information transparency of bankruptcy processes and the perception of the analyzed types of information as important. The answer to this question should confirm or refute our thesis that the three types of financial information used in bankruptcy proceedings support the task of ensuring information transparency in bankruptcy processes.

The above questions were formulated based on the literature review, the analysis of legal acts, and our previous experiences of the economic side of bankruptcy processes. Mathematical statistics methods will be used in the article. The presented results are part of wider research on the informational role of accounting in bankruptcy proceedings. 


\section{Accounting Information in Insolvency by Liquidation: Literature Review}

Accounting focuses on satisfying the information needs of stakeholders of entities that continue their business operations who - thanks to financial statements - form opinions on the future of an enterprise (cf. e.g. Hendriksen and Van Breda, 2002; Walińska and Jędrzejewski, 2009). However, the presence of accounting information during bankruptcy proceedings indicates that it can also be used in the event of a going concern assumption threat.

Research shows that court files from bankruptcy cases contain financial statements of indebted enterprises (Smith and Strömberg, 2005; Newton, 2010; Bauer, 2018a; Bauer, 2018b). The priority for the stakeholders of enterprises that undergo liquidation bankruptcy proceedings is to determine the principles adopted in their preparation, with particular regard for the going concern assumption.

The relationship between the principle of going concern assumption and bankruptcy by liquidation proceedings is emphasized in scientific research (e.g. Górowski, 2016; Hospodka, 2018; Pelák, 2018) However, the significance of this principle is much broader and results from the essence of accounting (cf. Hendriksen and Van Breda, 2002; Gierusz, 2006; Philipson, Johansson and Schley, 2016).

The going concern assumption was introduced for the first time in the Middle Ages when the ships that traded overseas needed to go on more than one trip with their cargo. For both entrepreneurs and investors, it would have been inefficient to liquidate all the assets after every voyage. The going concern assumption allowed the business to continue over time without the necessity to do so. (Philipson et al., 2016). Today, the principle is at the core of accounting principles and is considered a necessity in financial accounting.

However, who is responsible for the going concern? In most countries, this should be the statutory body of a company or its management as it has the best understanding of the company and its situation. If the management has any doubts about the entity's ability to continue as a going concern, it should disclose such information in notes to financial statements. This is required by most accounting standards around the world. In case the going concern assumption is no longer valid, and the company is not a going concern anymore, the statements should be adjusted accordingly. The highest level of detail of what to do in case of difficulties with going concern is provided by the US Generally Accepted Accounting Principles (GAAP). Generally, the problem might be that 
a company or its management is reluctant to disclose the fact that the going concern assumption is no longer valid. There are numerous reasons for this. First, the management is unaware of any future existential threats to the company, such as the impact of Covid-19 on its business, which we witness at present. Second, it might harm the management's interest to disclose such a fact. Some argue that this could be partly solved by mandatory management disclosure on the going concern assumption (Venutti, 2004). In the case of audited companies, the auditor should analyze the going concern and should be unwilling to give unqualified opinions on statements if they do not treat the going concern assumption correctly. However, we must not forget that auditing companies are usually paid by the companies themselves. Out of the twenty largest bankruptcy filings in the US history, twelve occurred in 2001 and 2002, and all of them had unqualified opinions from their auditors on their financial statements prior to the bankruptcies (Carnegie and Connell, 2014; Uang, Citron, Sudarsanam, and Taffler, 2006; Venuti, 2004; Philipson et al., 2016). However, accounting should focus not only on the ability of an entity to predict bankruptcy and its reflection in financial statements. In fact, accounting should also focus on entities that have already entered bankruptcy proceedings.

Research emphasizes that accounting marginalizes the information needs of entities in which there is a threat of going concern. For example, in Poland, when preparing the balance sheet for the day preceding the declaration of bankruptcy, the precautionary principle is used as a priority. This means that what is not taken into account when preparing the balance sheet are the needs of liquidators, for whom information about the real sale value of assets is important (Walińska and Jędrzejewski, 2009, pp. 165, 172). Hence, efforts are being made by stakeholders to obtain additional information on the value of assets but from a different perspective than just book value. This information is already important at the time of filing for bankruptcy as it shows real possibilities of conducting court proceedings and satisfying creditors' claims. In most of the countries researched by Smith and Strömberg (2005) the laws oblige the debtor to submit information on the value of assets already upon initiating bankruptcy proceedings, such as lists of estate assets and claims, sometimes financial statements or preliminary valuation of its assets.

Research conducted by Newton (2010) indicates that courts in the USA consider fair value in bankruptcy proceedings, which differs from market value by the revenue of forced transaction. Extending information on the value of assets by something else than just book value may be important to the correctness of court proceedings. This is confirmed by the results of research conducted in Poland (Bauer, 2015), which indicate discrepancies between the book value and estimated sale value of debtors' assets. The 
empirical studies indicate that balance sheet values of fixed assets are in most cases significantly lower than their estimated values. The results suggest that what is a justified course of action in the case of a threat to continuing operations is the use of estimates in which the value of assets is close to valuation at market prices, adjusted for the sale conditions forced by bankruptcy proceedings.

Therefore, we may conclude that having knowledge only about the carrying value of assets is insufficient to conduct bankruptcy proceedings. One of the reasons that necessitate the correct value assessment of potential streams of proceeds from the sale of debtors' assets is the assessment of their ability to cover the costs of bankruptcy, which can be significant.

Commenting on bankruptcy costs in the United Kingdom, Marsh (2010, p. 45) explicitly writes that, "[i]t is ironic, but it is quite expensive to go bankrupt." Initiating insolvency proceedings entails advance payments toward the costs of proceedings (Finch, 2012). Where estimated bankruptcy costs exceed the value of the bankrupt enterprise's assets, it results in the dissolution of the company, not in bankruptcy (Altman and Hotchkiss, 2006).

In accordance with Smith and Strömberg (2005), bankruptcy proceedings involve costs, both directly related to the bankruptcy procedure and indirect ones, e.g. the impairment of assets. In their opinion, bankruptcy law should support the effectiveness of insolvency proceedings, i.e. facilitate a quick conclusion of an agreement between the debtor and the creditors. Faster insolvency proceedings limit procedural costs and reduce losses resulting from a decrease in the liquidation value of the bankrupt's assets.

In accordance with Poland's Bankruptcy Law, the court shall dismiss the petition to declare bankruptcy when the assets of the insolvent debtor are insufficient to cover the cost of proceedings.

Cost analyses are largely used in preliminary insolvency proceedings as a basis for the court to decide whether to declare bankruptcy of an entity. However, there are no developed standards for this type of analysis, which impacts their detail, quality, and - in many cases - excludes the possibility of their use as a cost control tool during a bankruptcy trial. The role of court representatives is to look at costs ex ante by making estimates of their potential value. There also are no standards regarding the assessment of cost performance ex post (Bauer, 2013). The lack of standardization in this area is conducive to the use of cost accounting tools. Various solutions are proposed for the division and calculation of bankruptcy costs - along with the creation of bankruptcy 
costs accounting - as a management accounting tool that allows reducing costs to a level that enables the process to be conducted properly (Sojak and Trojanek, 2010).

\section{Legal Regulations of Accounting in Insolvency Proceedings: International Perspective}

Insolvency is to protect creditors so that they regain their debts, at least partially. The law is to guarantee this protection, with regulations that foster discipline and integrity in the financial management of an enterprise in which insolvency proceedings are conducted (Wessels, Markell, and Kilborn, 2009). Accounting rules for companies in insolvency proceedings vary significantly across different countries. This article investigates several countries in more detail. We will describe the basic regulations regarding the use of bankruptcy accounting in the USA, Canada, the Czech Republic, Slovakia, and Poland. We chose the legal regulations of these countries for research because we want to compare the rules in force in countries with a long tradition of bankruptcy (USA, Canada) with countries with a relatively short tradition of market economy and the resulting problems with bankruptcy.

\section{The Case of the United States of America}

The US GAAP specifically says that in case a company is no longer a going concern, it needs to adopt the so-called liquidation basis of accounting. As per the US GAAP, all assets should be measured at the estimated amount of cash that the entity expects to collect in settling or disposing of these assets during the process of liquidation. Any subsequent change to the carrying value of the assets should be accrued (ASC 205-30-30). Therefore, the US GAAP clearly states that the book value is no longer the correct approach to asset measuring. Moreover, the US GAAP clearly states that once the bankruptcy is imminent, the entity is no longer going concern.

The company should also change the set of financial statements to be published. Instead of standard statements, such as the balance sheet, the P\&L statements, or cash flow statement, it should publish the following statements (ASC-205-30-45):

- a statement of net assets in liquidation;

- a statement of changes in net assets in liquidation.

Both of these statements are fairly simple, and their goal is only to show what is important for companies in the insolvency proceedings. The main difference is that the assets 
are measured at a different value, as described above. The entities should also include several items in their statements. First, they should recognize items that were previously not recognized (e.g. trademarks), which are expected to be sold in the liquidation process or are going to be used to settle liabilities. Second, they should recognize all the liabilities that were not reported before. Third, they should accrue the estimated costs related to the disposal of assets that are expected to be sold during the liquidation process. These costs should be presented separately from other assets or items. Fourth, they should also accrue costs and incomes that they expect to incur or earn through the end of their liquidation, such as payroll costs or income from preexisting orders that the entities expect to fulfill during their liquidation processes.

This suggests that statements of net assets in liquidation should basically represent the current balance sheet and include all the future costs and income that will be borne by the company in proceedings. Generally, the US GAAP represents by far the most detailed approach to bankruptcy accounting. Furthermore, there is a much broader literature available on the topic compared to similar topics in other countries (e.g. Haskin and Haskin, 2012; Ratcliffe, 1991).

\section{The Case of Canada}

In Canada, bankruptcy is a matter of federal jurisdiction like in the USA. That is, bankruptcy in Canada is generally based on the two following laws:

1) the Bankruptcy and Insolvency Act (BIA);

2) the Companies Creditors Arrangement Act (CCAA).

Under both the BIA and CCAA, debtors are required to prepare the so-called statement of affairs, which represents an extended balance sheet and includes estimated current values of assets and amounts pledged as security and the estimated amount available to meet unsecured claims (Haskin and Haskin, 2012). The statement of affairs is a great tool for insolvency courts, creditors, and the general public to immediately gauge what is the actual financial situation of the debtor and in what amount will their claims be settled. The statement of affairs is required to be filed upon entry into bankruptcy proceedings.

Otherwise, the Canadian GAAP has been converged with the International Financial Reporting Standards (IFRS) for all publicly accountable enterprises, meaning there is no special accounting for companies in insolvency by liquidation. Privately accountable entities follow the Accounting Standards for Private Enterprises (ASPE), a Canadian set of standards. However, not even in the ASPE are there any specific guidelines for 
companies that have already entered insolvency proceedings. The ASPE only give them the information that, "[f]inancial statements are prepared on the assumption that the entity is a going concern, meaning it will continue in operation for the foreseeable future and will be able to realize assets and discharge liabilities in the normal course of operations. Different bases of measurement may be appropriate when the entity is not expected to continue in operation for the foreseeable future" (ASPE, §100.52). That is, the entities that enter bankruptcy should remeasure their assets and refrain from using book value.

However, the ASPE provides at least some clarity to creditors and how to account for their loans and receivables in case the counterparty entered insolvency.

\section{The Case of the Czech Republic}

In the Czech Republic, there is more than one source for accounting rules. The most important document for accounting rules and principles is the Accounting Act. However, this document offers almost no specific accounting and reporting requirements for companies that entered insolvency proceedings, besides certain technical requirements such as when to open and close accounting books or financial audit requirements.

The second main source of accounting rules is the Accounting Decree. This document contains no information on insolvency proceedings or going concern whatsoever. The highest level of detail appears in the Czech Accounting Standard no. 21, which solely focuses on companies in insolvency or restructuring proceedings. The major problem with this standard is that it has not been updated since 2004, even though there have been major changes to the insolvency and restructuring rules in the Czech Republic since then. The Standard gives the entities some information, such as that they should not report all accruals, prepayments, deferred items, and provisions that will not be verifiably used during insolvency proceedings. Furthermore, all assets and liabilities should be reported on the balance sheet, even those that are not part of the insolvency proceedings. Finally, new assets recognized during the proceedings should be booked as extraordinary income and an increase in assets.

Going concern is described in very vague terms in the Czech accounting law. Some even argue that the accounting rules to be adopted by an entity entering insolvency by liquidation are "quite a mystery" (Pelák, 2018). There are no specifics on what should change in terms of asset measurement when the going concern is no longer valid and whether the entity should keep using book value or not. 
The rules in the Czech Republic are inadequate compared to the US GAAP, which instructs the entities to prepare a completely new set of financial statements, gives both description and visual examples of these statements, and explicitly mentions on what basis the assets should be measured. If the bankruptcy administrator concludes that the asset value of an entity does not even cover the costs of the insolvency proceedings, the court should rule in favor of completely canceling the insolvency proceeding as such.

\section{The Case of Slovakia}

Slovakian accounting rules are described in the Slovakian Accounting Act, which historically stems from the same piece of legislation as the Czech one, as both countries used to be one until recently. Therefore, the information provided in the accounting act in relation to insolvency proceedings is very limited and again refers only to the technical aspect of accounting in insolvency. It does not provide individual companies with any guidelines on how to treat their accounting methods and financial statements in the case of insolvency proceedings. In the case of going concern and the use of book value, the approach is very similar to the one in the Czech Republic, which is almost non-existent. There are no clear guidelines on how to measure assets in case the entity enters insolvency by liquidation. It is also not clearly stated that the insolvency by liquidation is a clear sign that the going concern assumption is no longer valid.

\section{The Case of Poland}

Unlike in the Czech Republic and Slovakia, in Poland, there are different pieces of legislation for insolvency by liquidation and for restructuring. The main source of Polish accounting rules is the Accounting Act. It not only provides entities with guidelines on how to approach the going concern - also with guidelines on how to measure the asset value - but also mentions several details in regards to specifics of insolvency by liquidation, such as when to close and open the books, when to perform stocktaking, and that particular components within equity should be merged into one on the balance sheet (a similar rule was historically also present in the Czech Republic law). Similar to the Czech Republic, a company is no longer required to be audited after it entered insolvency by liquidation (Bauer and Hospodka, 2019).

However, Poland's accounting standards generally do not require the company to change the structure of their financial statements or provide many specific details on the accounting procedures for the company in insolvency by liquidation. This can be said about all the countries in our scope, apart from the USA. The US GAAP introduces 
new financial statements, gives guidelines on how to measure the value of assets properly, and describes at least some of the specifics related to insolvency.

Furthermore, we should indicate that the countries with a shorter tradition of the market economy (i.e. Poland, the Czech Republic, and Slovakia) tend to focus on technical aspects of insolvency - e.g. when to open and close the books or how to perform stocktaking - whereas the more traditional market economies (namely the USA) focus on true economic aspects of insolvency.

Noteworthy, one more element of insolvency proceedings documentation in Poland is the analysis of bankruptcy proceedings' costs. The element stems from accounting and was created to provide information necessary for the court to declare bankruptcy and select its kind. This analysis is created in the period between the filing of the request to declare bankruptcy and the court's decision to initiate bankruptcy proceedings or dismiss the claim. Accordingly, the interim court supervisor (or interim administrator) prepares periodical reports on the entity's activities and financial reports with justification. One of the elements of these reports is the analysis of bankruptcy proceedings' costs conducted ex ante, for the period between declaring bankruptcy and concluding bankruptcy proceedings. The purpose of this analysis is to enable the court to decide regarding the declaration of bankruptcy. This is because - in accordance with article 13 paragraph 1 of the Accounting Act - the court shall dismiss the petition to declare bankruptcy when assets of the insolvent debtor are not sufficient to cover the cost of proceedings. It is the duty of court representatives to analyze whether the costs of bankruptcy were conducted according to estimates made in the first stage of the process. The representative is to monitor this from the moment bankruptcy is declared until all bankruptcy proceedings are finalized. An analysis of the actual costs is a part of periodic statements of accounts prepared by representatives of the court. Because the costs of bankruptcy proceedings are one of the main financial categories used by the court when deciding about the future of an enterprise in debt, it is crucial for the estimates to be conducted in a reliable manner and not to differ significantly from the costs incurred (Prawo upadłościowe, 2003; Bauer, 2013 et al., 2019). The significance of calculating the costs of bankruptcy is emphasized by the results of studies conducted in law courts in Poland, conducted as part of the project "Effectiveness of bankruptcy procedures." Research shows that the costs of bankruptcy proceedings amount to $35 \%$ of the bankruptcy estate. The data for the research were obtained from the final reports of the syndic/bankruptcy trustee or periodical accounting reports (Morawska, 2013). Let us emphasize that the calculations of bankruptcy costs for the purpose of court proceedings differ from the concept of costs resulting from accounting. When drawing up accounting statements in court proceedings, accounting principles are not 
applied. This may cause the terms "cost" and "expense" to be used interchangeably, and the moment of incurring an expense is identified as the moment of incurring the cost (Bauer, 2013). Regardless of the differences in the approach to cost accounting, information about the costs is present in the company's accounting records during the bankruptcy process. Therefore, these analyzes can be considered appropriate for the subject matter discussed in this article.

\section{The Role of Accounting Information for Insolvency Experts: Empirical Evidence from Poland}

\section{Reasons for Undertaking Study}

Literature review and the analysis of legal regulations regarding information used in bankruptcy proceedings in various countries around the world indicate a differentiated approach to the informational role of accounting in the case of company bankruptcy.

Poland is a country where indebted enterprises are required to submit to court financial documentation originating in accounting, in particular financial statements. Due to relatively high information requirements compared to other countries' legal regulations and the information needs of stakeholders of entities undergoing liquidation bankruptcy proceedings disclosed in previous studies (Bauer, 2018a), we selected Poland as the country for an empirical study. The aim of the study was to reveal the position of bankruptcy specialists on the significance of financial information originating in accounting to ensure transparency of bankruptcy processes.

The study elaborated on the ideas of such authorities as E. Mączyńska (Mączyńska and Morawska, 2015, p. 201-203) who indicates that ensuring the efficient course of bankruptcy processes requires the understanding of the financial situation of a given entity and a chance to assess this entity. The assessment involves the use of financial data; its main source is the entity's financial statement. This is part of research on the role of insolvency institutions in reducing information asymmetry between parties to a court trial (cf. Smith and Strömberg, 2005).

\section{Study Procedure and Results}

The study consisted of a survey conducted on a sample of 103 bankruptcy specialists. This group included not only judges or trustees with in-depth legal knowledge and many years of experience in insolvency proceedings but also members of the Minister 
of Justice Council for the Amendment of Bankruptcy and Reorganization Law, who had a real impact on the new Bankruptcy Law, including financial information.

Questionnaires were filled out by:

- participants of the Third Congress of Restructuring Law in Warsaw, June 16-17, - bankruptcy practitioners who cooperate with the District Court for Krakow-Center in Krakow, the Eighth Economic Division for Bankruptcy-Restructuring and the Katowice-East District Court in Katowice, the $10^{\text {th }}$ Economic Division for Bankruptcy, District Court in Opole, Economic Division V, and

- bankruptcy practitioners working in law firms in Krakow and Warsaw.

In choosing the sample, the priority rule was the experience gained by respondents as a result of participation in ongoing bankruptcy and restructuring cases, but also the thorough knowledge of Bankruptcy Law (Prawo upadłościowe, 2003) and Restructuring Law (Prawo restrukturyzacyjne, 2015).

The sample included: ${ }^{3}$

- 29 judges conducting insolvency proceedings, ${ }^{4}$

- 12 members of the Minister of Justice Council for the Amendment of Bankruptcy and Reorganization Law, ${ }^{5}$

- 96 people who declared that they have practical experience in insolvency proceedings conducted in 2013-2015; 62 of them declared to also have practical experience in proceedings under Bankruptcy Law that came into effect in 2016.

The collected sample allowed us to assume that the completed questionnaires contain opinions of those who in their professional work influence the scope and even the quality of financial documentation collected in court for the purpose of bankruptcy proceedings.

\footnotetext{
3 Fifteen respondents indicated double occupational affiliation. One of the judges declared that his leading occupation was scientific work in the field of legal science. At the same time, he indicated that he had practical experience in insolvency proceedings.

4 The sample group includes a large percentage of insolvency judges. According to the data of the Association of Restructuring and Bankruptcy Judges, there are 12 departments in Poland that exclusively deal with bankruptcy cases. There is a total of 87.8 job positions for judges in these departments. Furthermore, there are 18 economic departments that also deal with insolvency cases. However, we do not know the number of judges who deal with insolvency proceedings in these departments.

5 The sample group includes answers of almost $43 \%$ of all members of the Justice Council for the Amendment of the Bankruptcy and Reorganization Law (the council consists of 28 members; Ministry of Justice, 2012).
} 
The conducted empirical study is part of a much broader research project regarding the informational role of accounting in restructuring and insolvency proceedings. The questionnaire contains 149 detailed questions. Four of them were chosen for the purpose of the analysis. The selected questions referred to assessment by bankruptcy specialists of the significance of financial information originating in accounting in ensuring the information transparency of insolvency proceedings.

The analysis of empirical research results was divided into three stages resulting from the literature review and legal regulations. We focus on legal regulations from Poland as the respondents of the sample were from Poland.

\section{First Stage of Empirical Study Results Analysis}

The literature review indicated that one of the main roles of the bankruptcy process is to provide financial information about the indebted enterprise, thereby reducing information asymmetry between parties to the legal process (Smith and Strömberg, 2005). Research indicates the need for measures that could expand access to financial information of a given indebted enterprise and to fulfill the expectations of bankruptcy specialists for an increase in the availability of financial statements (Bauer, 2018a). The information must pertain to various areas, including costs of bankruptcy proceedings (Prusak et al., 2019) and valuation methods used and the value of the debtor's assets (Smith and Strömberg, 2005; Altman and Hotchkiss, 2006; Newton, 2010; Bauer, 2015). Providing access to financial data in databases of bankruptcy processes increases their transparency and is a source of information for court representatives and creditors, i.e. stakeholders who do not have full access to the financial data of the indebted enterprise (Bauer, 2009; Bauer, 2018a; Bauer, 2018b). Actions to increase access to financial information of enterprises in bankruptcy processes should respond to the information needs of stakeholders of these processes (Bauer, 2018a). Therefore, in the first stage of the analysis, we sought to determine whether the respondents agree with the statement that one of the roles of the bankruptcy institution is to ensure the information transparency of bankruptcy processes.

First, the respondents were asked to evaluate to what extent they agree with the statement that ensuring information transparency is one of the key tasks of insolvency proceedings. They had six answers to choose from: "I totally disagree," "I rather disagree," "I half disagree," "I rather agree," "I totally agree," and "I don't know." Of the 102 people who answered this question, only 2 selected the last possibility while the vast majority were able to respond to the question more precisely. The distribution of answers is presented in Figure 1. 
Figure 1. Distribution of answers to the question: is ensuring information transparency one of the key tasks of the bankruptcy proceeding?

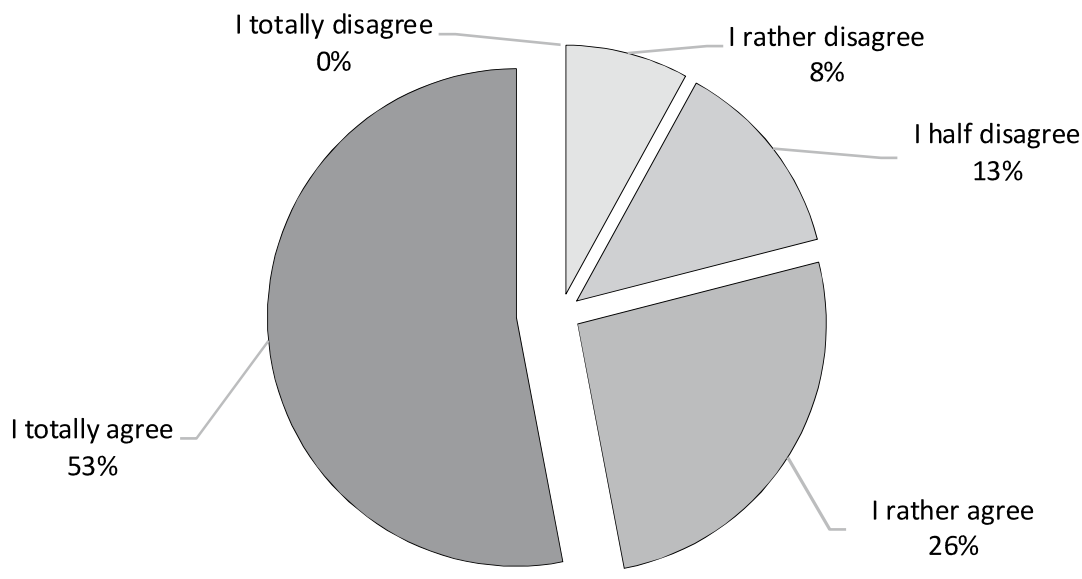

Source: own elaboration.

More than half of the respondents (53 people, $53 \%$ of the respondents) fully agree with the statement that ensuring information transparency is one of the key tasks of insolvency proceedings, while another 26 people rather agreed with this statement. There was not a single respondent who totally disagreed with the analyzed statement. This means that ensuring information transparency is broadly recognized by insolvency specialists as an important aspect of insolvency proceedings.

\section{Second Stage of Empirical Research Results Analysis}

As a result of the literature review and the analysis of legal acts, we noticed that three types of information were indicated as necessary to decide about the indebted enterprise. The first type of information results from both theory and legal regulations used in Poland. Researchers emphasize the importance of information on the costs of bankruptcy proceedings for the purpose of conducting bankruptcy proceedings (e.g. Altman and Hotchkiss, 2006; March, 2010; Finch, 2012; Morawska, 2013; Bauer, 2013; Staszkiewicz and Morawska, 2019; Prusak et al., 2019). The need to conduct analyses on the costs of insolvency proceedings is also indicated in Bankruptcy Law.

Prusak et al. (2019) draw attention to the role of determining the costs of bankruptcy in the context of Bankruptcy Law's effectiveness. In their opinion (2019, p. 63), "Bankruptcy law is effective in the ex-ante stage when it eliminates from the market insolvent entrepreneurs who cannot even afford to cover the costs of bankruptcy proceedings. 
In such cases, the bankruptcy court should dismiss the petition for bankruptcy due to the "poverty" of the insolvent estate." In Poland, a reference to the significance of bankruptcy costs can be found in Article 13 of Bankruptcy Law, which stipulates that "the court shall dismiss a bankruptcy petition if an insolvent debtor's assets are insufficient to cover the costs of proceedings or are only sufficient to cover such costs." The cost of the bankruptcy process is displayed in the accounting records of the debtor's enterprise. Therefore, although the recognition of costs itself differs from the accounting principles and is rather cash-based (it is equivalent to the expense incurred), we may nevertheless assume that this information has its source in accounting, following the nature of the documentation that constitutes the basis for recording bankruptcy process costs.

The second type of information relevant to bankruptcy processes is information about the going concern assumption. In accounting theory, the going concern principle is indicated as particularly significant (cf. e.g. Sunder, 1997; Dobija, 1999; Hendriksen and Van Breda, 2002; Gierusz, 2006; Hołda, 2006) Among other things, this information indicates the use of the valuation method when preparing financial statements and the statements that are also necessary for assessing the condition of the indebted enterprise. As noted by Górowski and Kurek (2019a, p. 186-189), the decision to adopt the going concern assumption is in practice a difficult and complex process that often requires the preparation of long-term forecasts regarding the complexity of economic processes. At the same time, the Bankruptcy Law does not require the debtor to provide additional information to financial statements that would specify whether it was prepared with the going concern assumption. Earlier empirical research conducted in Poland proved that practice shows a differentiated approach to accepting (or rejecting) the going concern assumption by debtors who prepare financial statements. What results from the analysis of court documentation of bankruptcy proceedings (Bauer, 2016, p. 130), there are confirmed cases in which debtors who file for bankruptcy leading to the liquidation of assets provide financial statements prepared under the assumption of the continuation of activities. The balance sheets submitted by debtors and the financial statements prepared by trustees on the day preceding the declaration of bankruptcy are not the only sources of information about the value of assets of the indebted entity. The practice of bankruptcy proceedings also employs estimates prepared by court representatives. However, in cases without an appointed interim court supervisor or trustee, ${ }^{6}$ information from the balance sheet is critical in determining

\footnotetext{
6 Research conducted on a sample of 100 randomly selected enterprises that were declared bankrupt in 2011 shows that in 26 cases a temporary court supervisor was not appointed. The groundwork for the decision on the possibility of conducting bankruptcy proceedings was made by the court based on the balance sheet and the estimated property valuation conducted by the debtor (Bauer, 2015, p. 13-14).
} 
the value of the estate (Bauer, 2015). There can also be a case in which the trustee running the bankrupt's business does not foresee the cessation of activity in the near future (Górowski, 2016, p. 244). Therefore, stakeholders in the bankruptcy process - including court rulings on bankruptcy - do not have information on the methods used to measure balance sheet values of assets (Bauer, 2018a). Thus, more research is required into the needs of insolvency practitioners regarding the information on the going concern assumption.

The third type of information used in bankruptcy processes is information about the book value of assets. The Bankruptcy Law obligated indebted enterprises to submit balance sheets to court. However, the usefulness of information on the book value of assets is questioned in the literature because it significantly differs from the sale value of assets (Mączyńska, 2009; Bauer, 2015). A significant limitation to the information role of accounting in the bankruptcy process is that the precise application of balance sheet law provisions may lead to a distorted assessment of an entity's financial situation (Mączyńska, 2009). Research conducted in Poland regarding book value and estimated sales value proved significant differences between the two values (Bauer, 2015). At the same time, as we indicated above, there are cases in which the balance sheet is the only source of information on the debtor's assets at the initial stage of bankruptcy proceedings. Due to information ambiguity whether the book value of assets is needed in the bankruptcy process, we call upon the opinion of bankruptcy specialists regarding this issue.

At this stage of our study, bankruptcy specialists assessed the significance of three types of indicated information. The questions were worded as follows:

Please assess the importance of the following types of information to ensure the information transparency of insolvency proceedings by using a scale of 1 to 5 (in which 1 means "completely irrelevant information" and 5 means "crucial information"). The information regards:

- costs of bankruptcy proceedings,

- the going concern assumption adopted in financial statements,

- the book value of assets.

"I don't know" or "not applicable" was a possible answer to each question. The distribution of answers to the questions asked is presented in Table 1, and the comparison of cumulative shares of individual assessment is presented in Figure 2. 
Table 1. Distribution of assessments of insolvency specialists regarding the types of information listed below

\begin{tabular}{|c|c|c|c|c|c|c|c|}
\hline \multirow{2}{*}{ Information on: } & \multicolumn{5}{|c|}{$\begin{array}{l}\text { number of individual assessments } \\
\text { on a scale of } 1 \text { to } 5\end{array}$} & \multirow{2}{*}{$\begin{array}{c}\text { number of } \\
\text { “I don't know" } \\
\text { "not applicable" } \\
\text { answers }\end{array}$} & \multirow{2}{*}{$\begin{array}{c}\text { no } \\
\text { answer }\end{array}$} \\
\hline & 1 & 2 & 3 & 4 & 5 & & \\
\hline $\begin{array}{l}\text { the costs of bankruptcy } \\
\text { proceedings }\end{array}$ & 1 & 5 & 8 & 39 & 46 & 2 & 2 \\
\hline $\begin{array}{l}\text { the going concern assumption } \\
\text { adopted in the financial } \\
\text { statements }\end{array}$ & 2 & 7 & 22 & 44 & 23 & 3 & 2 \\
\hline the book value of assets & 7 & 18 & 28 & 20 & 24 & 4 & 2 \\
\hline
\end{tabular}

Source: own elaboration.

Figure 2. Comparison of cumulative shares of bankruptcy specialists' assessments regarding the types of information listed below

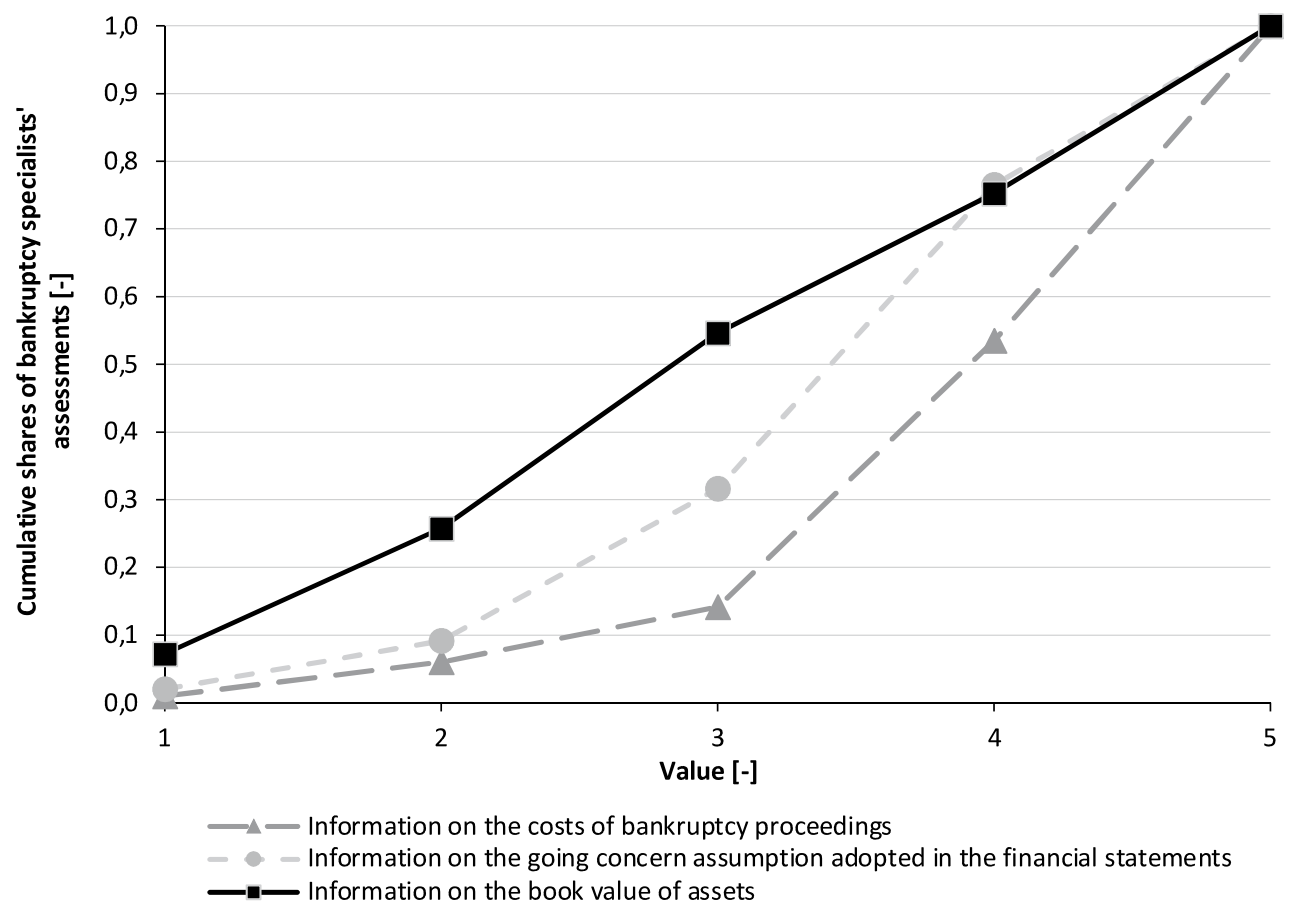

Source: own elaboration. 
As a result of the conducted research, we found that the vast majority of respondents indicated as significant or very significant the information on the costs of bankruptcy proceedings. This information was marked as important by 85 participants, i.e. almost 83\% of the respondents. Let us emphasize that, in Poland, information on the costs of bankruptcy proceedings included in bankruptcy proceedings' court files deviates from accounting principles. When preparing accounting statements, to calculate the costs of insolvency proceedings, court representatives use the cash method, i.e. they calculate planned and executed expenses related to court proceedings in progress (Prawo upadłościowe, 2003; Bauer, 2013). Despite the differences in the calculation of costs in terms of financial accounting and the guidelines contained in the Bankruptcy Law, the source of data about bankruptcy costs is the debtor's financial documentation.

Bankruptcy specialists indicated yet another important information on the method adopted in the preparation of financial statements when there is no continuity of operations. This information was indicated as significant or very significant by 77 respondents, i.e. nearly $75 \%$ of all respondents. This is especially important when there is no Bankruptcy Law requirement to submit a balance sheet to court, thus users of the information have no knowledge of which method of valuation was adopted.

Among the types of information that the respondents examined, the information on the book value of assets was ranked the lowest. Only 44 people, i.e. $43 \%$ of all respondents, considered this matter significant or very significant. Meanwhile, 28 respondents considered this information to be of medium importance (i.e. 27\%), while 25 people indicated this information as insignificant or of little importance (i.e. 24\%). Such results agree with previous research that emphasized the role of information about the liquidation value of assets in bankruptcy processes and the differences between the liquidation value of assets and their book value (for more, see Bauer, 2015).

The average value of assessments was considered the best comparative measure to determine the differences in the significance of examined information. Figure 3 below presents the comparison of average values for the qualitative features of the financial statements in bankruptcy proceedings, along with standard errors for each type of information.

Standard deviations of every assessment value were also included, which amounted to 0.88 (information on the costs of bankruptcy proceedings), 0.95 (information on the going concern assumption adopted in the financial statements), and 1.24 (information on the book value of assets). This yields relatively low values of standard errors, which 
are 0.09 (2.1\%), $0.10(2.5 \%)$, and 0.13 (3.7\%), respectively. Therefore, we may conclude that the results we obtained are reliable.

Figure 3. Comparison of average values for each type of information used in the bankruptcy process

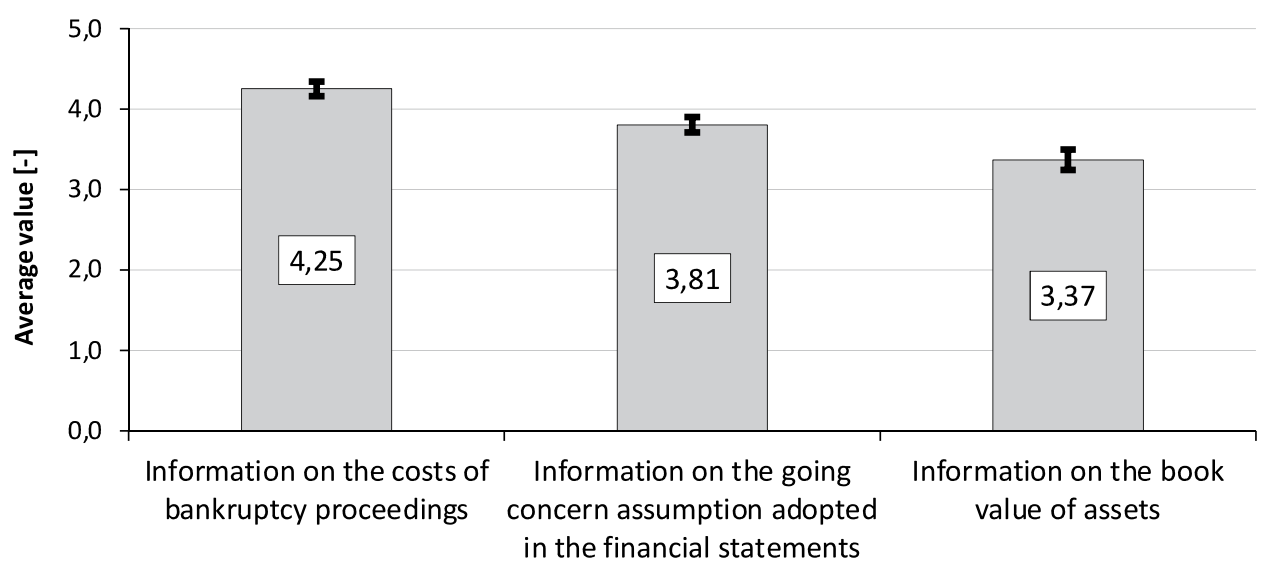

Source: own elaboration.

\section{Third Stage of Empirical Research Results Analysis}

The dependencies between the views of respondents included in the first and second stage of the analysis were checked in the last stage of the research. The final stage aimed at confirming or refuting the thesis that the three groups of financial information used in bankruptcy processes support information transparency in bankruptcy processes.

Respondents divided into two groups: they either completely agreed with the statement that ensuring transparency of information is one of the key tasks of insolvency proceedings or they informed that they are not entirely convinced (respondents rather agreeing or semi-agreeing, and those who rather disagree with this statement). This division was made at the first stage of the analysis and simplified due to the significant stratification of the sample.

The next checked aspect was whether the level of certainty about the need to ensure information transparency was related to validity assessments of three types of information necessary to make decisions about an indebted enterprise, which were examined in the second stage of our analysis. Therefore, we considered the assessment of the significance of information on the costs of bankruptcy proceedings, on the 
assumption of an entity's failure to continue business operations, and on the book value of assets. The comparison of average scores and values of standard errors is shown in Figure 4 below.

Figure 4. Comparison of average values for each type of information used in bankruptcy processes

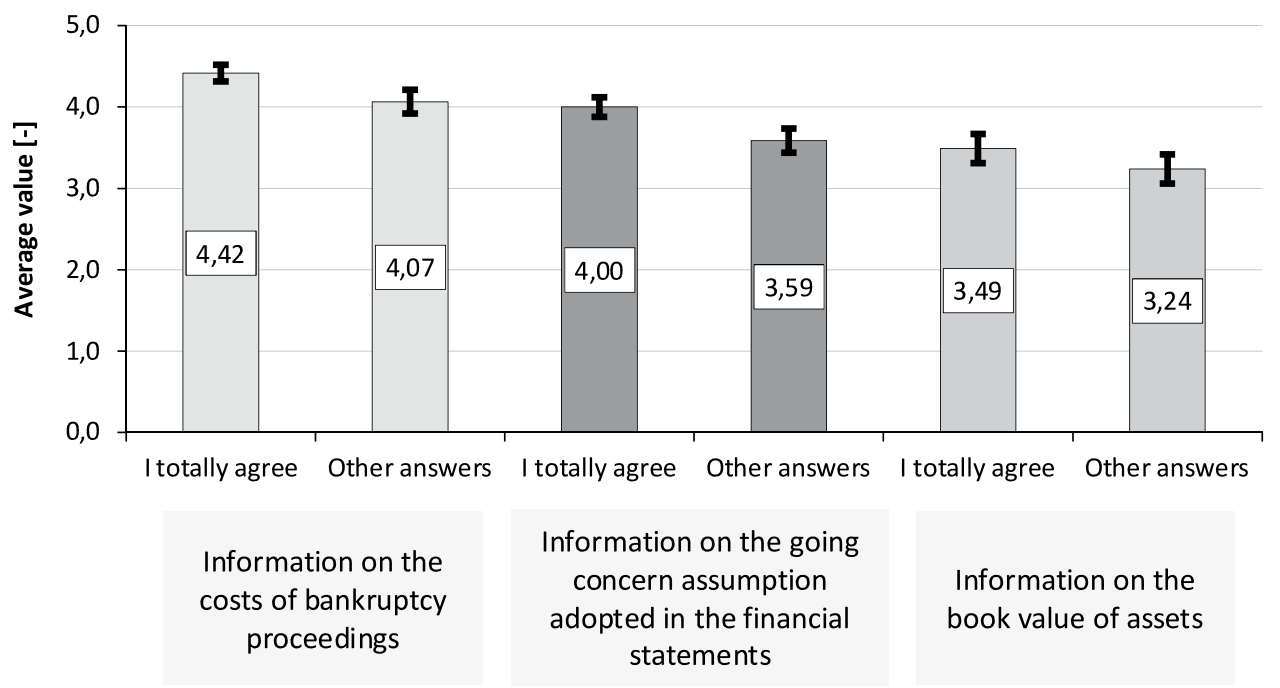

Source: own elaboration.

We may notice that for every three assessments of the validity of the three types of information necessary to decide about an indebted enterprise, respondents completely certain of the important role of information transparency rated this importance higher than respondents less convinced. Due to the significance tests for two averages, we found that in the first two cases - information on the costs of proceedings and on the going concern assumption adopted in financial statements - these are statistically significant differences (at the significance level of 0.05). Only the last case - information on the book value of assets - allowed us to confirm a statistically significant difference in ratings in the two defined groups of respondents.

The comparison of standard evaluation errors in the first two cases showed that lower error values were observed in the groups of respondents certain of the significant role of information transparency than in the case of other respondents; only the third case - information on the book value of assets - presented no such situation as the error values were equal. 
The study results in the third stage of the analysis indicate a well-established position among bankruptcy specialists about the importance of the three types of information indicated in the literature and legal regulations as important for ensuring the information transparency of bankruptcy processes. The respondents' opinion fits into the idea of the role the institution of bankruptcy plays in reducing information asymmetry between parties to court proceedings. The role of the bankruptcy institution in reducing information asymmetry is highlighted in publications of e.g. Smith and Strömberg (2005) and Bauer (2009).

The results of our empirical research agree with the views presented in the literature. Scientific publications by e.g. Altman and Hotchkiss, (2006), March (2010), Finch (2012), Morawska (2013), Bauer (2013), Staszkiewicz and Morawska, (2019), and Prusak et al. (2019) indicate the importance of information about the costs of bankruptcy proceedings for the purpose of a trial. Bankruptcy specialists also emphasized the role of information on the costs of bankruptcy proceedings.

The respondents also indicated the need to have information on whether the going concern assumption had been adopted or not, which corresponds to the notion contained in scientific works about enterprises in general (Sunder, 1997; Dobija, 1999; Hendriksen and Van Breda, 2002; Gierusz, 2006; Hołda, 2006) and especially the case of bankruptcy proceedings (Bauer, 2015; Bauer, 2016, Górowski, 2016; Bauer, 2018a).

Doubts regarding the usefulness of information on the book value of assets in the bankruptcy process indicated by Mączyńska (2009) and Bauer (2015) are also noticeable among the respondents. Not only is the average evaluation - in this case - lower but there also appear more low marks in this area than regarding other surveyed information. To summarize, the above research confirms the significance of information derived from accounting. However, the assessment of individual types of information differs.

\section{Conclusions}

This article reviewed the issues with accounting information relevant to reducing information asymmetry between parties to bankruptcy processes. Our analysis of the main legal regulations regarding accounting in processes of liquidation bankruptcy was conducted in select countries, both those with a long tradition of insolvency proceedings - such as the USA and Canada - and those with a relatively short history of insolvency proceedings, such as the Czech Republic, Slovakia, and Poland. As a result of these studies, three types of information were distinguished, i.e. the costs 
of bankruptcy proceedings, the going concern assumption, and the book value of assets. In the final research stage, we conducted surveys among bankruptcy specialists from Poland to determine their position on the significance of the studied information that originates in the debtor's financial documentation.

The study was conducted on a sample of 103 respondents connected to bankruptcy processes through practice in bankruptcy proceedings, scientific work related to the legal or economic side of bankruptcy processes, and in-depth knowledge of bankruptcy law. The study group of specialists also includes scientists who specialize in accounting. The main purpose of the study was to determine which accounting information is relevant for bankruptcy specialists. As a result, we indicated that bankruptcy specialists view all types of information originating in the company's accounting documentation as relevant. The application of mathematical statistics methods allowed us to establish that bankruptcy specialists give priority to information on the costs of insolvency proceedings. Less significant yet important information for bankruptcy specialists was the lack of the going concern assumption when preparing financial statements. The least important information for bankruptcy specialists was the book value of assets. Noteworthy, the obtained assessments of individual quality features show high reliability confirmed by low standard errors (maximum 0.13 [-], i.e. 3.7\%). Furthermore, we established that the assessment of the validity of ensuring information transparency in bankruptcy proceedings related to the assessment of the significance of information on the costs of insolvency proceedings and the assessment of information in the financial statement about the assumption that the entity did not continue as a going concern.

The research results contributed to further analyses related to the role of accounting in the bankruptcy proceedings of enterprises. The literature will continue to address bankruptcy professionals' need for various types of information. A comprehensive analysis ought to provide an answer to where does information hierarchy contain the accounting information database of bankruptcy processes. A certain limitation of the above research is the relatively small population of bankruptcy specialists in Poland. However, we will attempt to expand the research sample in the near future. In-depth knowledge of various aspects of the economic side of the phenomenon of bankruptcy is part of the current trend of minimizing its negative effects. 


\section{References}

Altman, E.I. and Hotchkiss, E. (2006). Corporate financial distress and bankruptcy: Predict and avoid bankruptcy, analyze, and invest in distressed debt. Hoboken, New Jersey, NJ: John Wiley \& Sons, Inc.

Altman, E.I., Sabato, G. and Wilson, N. (2008). The value of qualitative information in SME risk management. Journal of Financial Services Research, 40(2).

Banasik, P. (2017). Sq̨d zaangażowany społecznie - pożq̨dany kierunek zmian. Warszawa: C.H. Beck.

Bauer, K. (2016). The Understandability of Financial Statements in the Decision-making Processes of Insolvency Proceedings. Argumenta Oeconomica Cracoviensia, 14, 119-134. https://doi.org/10.15678/AOC.2016.1406.

Bauer, K. (2009). Zarzq̨dzanie informacjami w procesie upadłościowo - naprawczym przedsiębiorstw. Kraków: Wydawnictwo Uniwersytetu Jagiellońskiego.

Bauer, K. (2013). Decyzyjny rachunek kosztów postępowania upadłościowego. Prace Naukowe Uniwersytetu Ekonomicznego we Wrocławiu, 289, 43-52.

Bauer, K. (2015). Impact of Owner-Occupied Property Valuation by Historical Cost on Fixed Assets Value at Bankruptcy Risk. Management and Business Administration. Central Europe, 2, 3-23. https://doi.org/10.7206/mba.ce.2084-3356.138.

Bauer, K. (2018a). Sprawozdanie finansowe jako źródło informacji dla interesariuszy zewnętrznych przedsiębiorstwa w procesie upadłości. Zeszyty Teoretyczne Rachunkowości, 96(152), 9-25. https://doi.org/10.5604/01.3001.0011.6167.

Bauer, K. (2018b). Hierarchia cech jakościowych sprawozdań finansowych przedsiębiorstw w postępowaniu upadłościowym. Zeszyty Teoretyczne Rachunkowości, 98(154), 25-42. https://doi.org/10.5604/01.3001.0012.1545.

Bauer, K. and Hospodka, J. (2019). Rules for preparation and publishing of financial statements in bankruptcy and reorganization proceedings - evidence from Poland and the Czech Republic. Conference proceedings ACFA 2019. Prague: University of Economics in Prague.

Bauer, K., and Krasodomska, J. (2015). The premises for corporate social responsibility in insolvency proceedings. Research Papers of the Wroclaw University of Economics/Prace Naukowe Uniwersytetu Ekonomicznego we Wroclawiu, 387, 20-29.

Bauer, K., Hońko S., Orzeszko T., and Szadziewska A. (2020). Informacje finansowe i niefinansowe w ocenie działalności banków. KatowiceWydawnictwo IUS Publicum, Katowice.

Boratyńska, K. (2016). FsQCA in corporate bankruptcy research. An innovative approach in food industry, Journal of Business Research, 69(11), 5529-5533.

https://doi.org/10.1016/j.jbusres.2016.04.166.

Boratyńska, K. and Grzegorzewska, E. (2018). Bankruptcy prediction in the agribusiness sector: Lessons from quantitative and qualitative approaches. Journal of Business Research, 175-181. https://doi.org/10.1016/j.jbusres.2018.01.028.

Caprio, G. and Klingebiel, D. (1996, April). Bank insolvency: bad luck, bad policy, or bad banking? Annual World Bank conference on development economics, 79, 1-29.

Carnegie, G.D., and O'Connell, B.T. (2014). A longitudinal study of the interplay of corporate collapse, accounting failure and governance change in Australia: Early 1890s to early 2000s. Critical Perspectives on Accounting, 25(6), 446-468.

Chartered Professional Accountants of Canada (2018). Accounting standards for private enterprises (ASPE). [online]. [cit. 2018.08.02]. Available at: http://laws-lois.justice.gc.ca/eng/acts/C-36/.

Dobija, M. (1999). Rachunkowość zarzq̨dcza i controlling. Warszawa: Wydawnictwo Naukowe PWN. 
Donaldson, T., and Preston, L.E. (1995). The stakeholder theory of the corporation: Concepts, evidence, and implications. Academy of management Review, 20(1), 65-91.

Evan W., and Freeman R., (1997). A stakeholder theory of the modern corporation: Kantian capitalism. In: T. Beauchamp and N. Bowie (eds.), Ethical Theory and Business. New York: Englewood Cliffs, Prentice Hall.

FASB (2017). FASB Accounting Standards Codification Notice to Constituents. (US GAAP). [online]. [cit. 2018.08.02]. Available at: https://asc.fasb.org/.

Finch, B. (2012). Insolvency and financial distress. How to avoid it and survive it. London: Bloomsbury Publishing.

Gierusz, J. (2006). Koszty i przychody w świetle nadrzędnych zasad rachunkowości (pojęcia, klasyfikacja, zakres ujawnień). Gdańsk: Ośrodek Doradztwa i Doskonalenia Kadr.

Górowski I., and Kurek B. (2019). Założenie kontynuacji działalności - aspekt menedżerski. In: S. Hońko, A. Lulek (red.), Rachunkowość finansowa w zarzq̨dzaniu jednostkami gospodarczymi. Rozprawy i Studia T. (MCLXVIII) 1094, Szczecin: 185-199.

Górowski, I. (2016a). Rola ksiąg rachunkowych w ocenie stanu niewypłacalności przedsiębiorstw w świetle nowych regulacji prawa upadłościowego. Studia Ekonomiczne, 285, 208-217.

Górowski, I. (2016b). Weryfikacja założenia kontynuacji działalności-rola biegłego rewidenta w systemie ładu korporacyjnego. Studia Prawno-Ekonomiczne, 101, 241-253.

Government of Canada (1985a). Bankruptcy and Insolvency Act. (R.S.C., 1985, c. B-3). [online]. [cit. 2018.08.04]. Available at: http://laws-lois.justice.gc.ca/eng/acts/B-3/

Government of Canada (1985a). Companies' Creditors Arrangement Act (R.S.C., 1985, c. C-36). [online]. [cit. 2018.08.02]. Available at: http://laws-lois.justice.gc.ca/eng/acts/C-36/

Government of Canada (2018). Form 78-Statement of Affairs (Business Bankruptcy/Proposal). [online]. [cit. 2018.08.02]. Available at: https://www.ic.gc.ca/eic/site/bsf-osb.nsf/eng/br02195.html

Haskin, D.L. and Haskin, T.E. (2012). Hierarchy of US GAAP vs. IFRS - the Case of Bankruptcy Accounting. International Business \& Economics Research Journal. The Clute Institute. https://doi.org/10.19030/iber.v11i4.6874.

Hendriksen, E.A. and Van Breda, M.F. (2002). Teoria rachunkowości. Warszawa: Wydawnictwo Naukowe PWN.

Hołda, A. (2006). Zasada kontynuacji działalności i prognozowanie upadłości w polskich realiach gospodarczych. Kraków: Wydawnictwo Akademii Ekonomicznej w Krakowie.

Hospodka, J. (2018). Analysis of going concern assumption. Economics Management Innovation. 2018. Available at: http://www.emijournal.cz/

Krasodomska, J. (2014). Informacje niefinansowe w sprawozdawczości spółek. Zeszyty Naukowe Uniwersytetu Ekonomicznego w Krakowie, Seria Specjalna: Monografie, 232. Kraków: Wydawnictwo Uniwersytetu Ekonomicznego w Krakowie.

Kurek, B. (2017), Zawartość informacyjna transakcji pakietowych akcjami na przykładzie rynku głównego Giełdy Papierów Wartościowych w Warszawie, Zeszyty Naukowe Uniwersytetu Ekonomicznego w Krakowie, Seria Specjalna: Monografie, 250. Kraków: Wydawnictwo Uniwersytetu Ekonomicznego w Krakowie.

Kurek, B. and Górowski, I. (2019), Kary nakładane przez Komisję Nadzoru Finansowego za naruszenie obowiązków informacyjnych w zakresie sprawozdawczości finansowej. Zeszyty Teoretyczne Rachunkowości, 102(158), 111-129.

Linna, T. (2019). Insolvency proceedings from a sustainability perspective. International Insolvency Review, 28(2), 210-232. https://doi.org/10.1002/iir.1345. 
Linna, T. (2020). Business Sustainability and Insolvency Proceedings-The EU Perspective. Journal of Sustainability Research, 2(2): 1-28. https://doi.org/10.20900/jsr20200019.

Marsh, D. (2010). Bankruptcy, Insolvency and the Law. Brighton: Straightforward Publishing.

Mączyńska, E. (2009). Zagrożenia w działalności gospodarczej. Dylematy ustrojowo-strategiczne. In: E. Mączyńska (ed.), Meandry upadłości przedsiębiorstw. Klęska czy druga szansa. Warszawa: Oficyna Wydawnicza SGH.

Ministry of Finance of Slovakia (2002). Decree of the Ministry of Finance of Slovakia on accounting (SK Accounting Decree).

Ministry of Finance of Slovakia (2002). Act no. 431/2002 Col,. on Accounting (SK Accounting Act)

Ministry of Finance of the Czech Republic (1991). Act No. 561/1991 Coll. on accounting (Accounting Act).

Ministry of Finance of the Czech Republic (2002). Decree No. 500/2002 Coll. on accounting (Accounting Decree).

Ministry of Finance of the Czech Republic (2018), Czech Accounting Standards. [Online]. Available at: http://www.mfcr.cz/cs/verejny-sektor/ucetnictvi-a-ucetnictvi-statu/ucetni-reforma-verejnych-financi-ucetnic/pravni-predpisy/platne-ceske-ucetni-standardy/2018/ceske-ucetni-standardypro-ucetni-jednot-30742

Ministry of Justice of Slovakia (2005). Act no. 7/2005 Coll, on Bankruptcy liquidation and Reorganization.

Mączyńska, E. and Morawska, S. (2015). Efektywność procedur upadłościowych. Bankructwa przedsiębiorstw, katharsis i nowa szansa. Warszawa: Oficyna Wydawnicza SGH.

Morawska, S. (2013). Przedsiębiorca w obliczu upadłości. Diagnoza i propozycje zmian systemu instytucjonalnego w Polsce, Warszawa: Oficyna Wydawnicza Szkoła Główna Handlowa w Warszawie.

Morawska, S., Roszkowska, P. (2011). Interesariusze w procesie upadłości przedsiębiorcy. Kwartalnik Nauk o Przedsiębiorstwie, 19(2), 49-58.

Newton, G.W. (2010). Bankruptcy and Insolvency Accounting. Practice and Procedure. Volume 1. John Wiley \& Sons, Inc.

Ogan, P. and Ziebart, D.A. (1991). Corporate reporting and the accounting profession: An interpretive paradigm. Journal of Accounting, Auditing \& Finance, 6(3), 387-406.

Pelák, J. (2018). Různé role auditora v oblasti insolvence. In: Bulletin Komory certifikovaných účetních. Published 04/2018.

Philipson, S., Johansson, J. and Schley, D.G. (2016). Global Corporate Governance: The Maelstrom of Increased Complexity - Is it Possible to Ride the Dragon? Journal of Business and Economics. https://doi.org/10.15341/jbe(2155-7950)/03.07.2016/007.

Prusak, B., Morawska, S., Kuczewska, J., and Banasik, P. (2019). The role of stakeholders on rejection of bankruptcy applications in the case of "poverty" of the estate: A Polish case study. International Insolvency Review, 28(1), 63-85. https://doi.org/10.1002/iir.1329.

Ratcliffe, T. and Munter, P. (1991). Financial reporting under Chapter 11. The CPA Journal. New York State Society of CPAs.

Smith, D.C. and Strömberg P. (2005). Maximizing the value of distressed assets: Bankruptcy law and the efficient reorganization of firms. In: P. Honohan, L. Laeven, Systemic Financial Crises. Containment and Resolution. New York: Cambridge University Press.

Sojak, S. and Trojanek, M. (2010). Rachunek kosztów upadłości. In: S. Sojak (ed.), Założyć firmę i nie zbankrutować-studia przypadków. Warszawa: Difin. 
Staszkiewicz, P. and Morawska, S. (2019). The efficiency of bankruptcy law: evidence of creditor protection in Poland. European Journal of Law and Economics, 48(3), 365-383. https://doi.org/10.1007/s10657-019-09629-2.

Sunder, S. (1997). Theory of accounting and Control. Cincinnati, Ohio: International Thomson Publishing.

Tilt, C.A. (2007). External stakeholders' perspectives on sustainability reporting. In: J. Unerman, J. Bebbington and B. O'Dwyer (eds.), Sustainability Accounting and Accountability. New York: Routledge.

Uang, J.Y., Citron, D.B., Sudarsanam, S. and Taffler, R.J. (2006). Management going-concern disclosures: Impact of corporate governance and auditor reputation. European Financial Management, 12(5), 789-816.

Ustawa z dnia 15 maja 2015 r., Prawo restrukturyzacyjne, Dz.U. 2015, poz. 978.

Ustawa z dnia 28 lutego 2003 r. Prawo upadłościowe, Dz.U. 2003, nr 60, poz. 535, ze zm.

Ustawa z dnia 29 września 1994 r. o rachunkowości, Dz.U. 1994, nr 121, poz. 591, z późn. zm.

Venuti, E.K. (2004). The going concern assumption revisited: Assessing a company's future viability. Accounting Auditing, The CPA Journal.

Walińska E. and Jędrzejewski, S. (2009), Bilans w warunkach utraty kontynuacji działalności-zasada ostrożności czy treść ekonomiczna. Zeszyty Teoretyczne Rachunkowości, 51(107), 165-176.

Wędzki, D. (2015). Analiza wskaźnikowa sprawozdania finansowego wg polskiego prawa bilansowego. Warszawa: Wolters Kluwer Polska.

Wessels, B., Markell, B.A., and Kilborn J.J. (2009). International cooperation in bankruptcy and insolvency matters. A joint research project of American College of Bankruptcy and Insolvency Institute. New York, NY: Oxford University Press.

Wójcik-Jurkiewicz, M. and Karczewska, M. (2019). Assessment of the Going Concern Value of a Business Entity by Means of Selected Discriminative Models, Zeszyty Naukowe/Wyższa Szkoła Finansów i Prawa w Bielsku Białej, (1): 53-60. https://doi.org/10.5604/01.3001.0013.1644.

Zorn, M.L., Norman, P.M., Butler, F.C. and Bhussar M.S. (2017). Cure or curse: Does downsizing increase the likelihood of bankruptcy? Journal of Business Research, 76, 24-33.

https://doi.org/10.1016/j.jbusres.2017.03.006. 